\title{
Shelter Trenches, or Temporary Cover for Troops in Position
}

\section{Colonel Gerald Graham V.C., C.B., R.E.}

To cite this article: Colonel Gerald Graham V.C., C.B., R.E. (1870) Shelter Trenches, or Temporary Cover for Troops in Position, Royal United Services Institution. Journal, 14:60, 448-478, DOI: $10.1080 / 03071847009421765$

To link to this article: http://dx.doi.org/10.1080/03071847009421765

册 Published online: 25 Sep 2009.

Submit your article to this journal $\sqsubset \pi$

Џ Article views: 3

Q View related articles ๘ 


\section{IJETURE.}

Frịday, 24th June, 1870.

Major-Gremal D. RUSSELL, C.B., in the Chair.

\section{SHELTER TRENCHES, OR TEMPORARY COVER FOR TROOPS IN POSI'TION.}

\section{By Colonel Ger.lud Gr.1Hur, w.e., C.B., R.E.}

Snelter-trexches (tranchées-abris) maj be considered a rapid application of field fortification for temporary purposes. "They may be defincd as having rather the character of ofleusive than of defensive fortification, resembling in their functions more the besiegers' parallels, or "places of arms" than intrenchments for the defence of a position, but they must always be considered as supplementary to natural cover and not as a substitute for it. In fact, as the title of this paper indicates, the primary object of "shelter trenches" is to obtain cover for troops in a giren position, without iuterfering with their adrance when required. Yet shelter-trenches may be combined with more purely defensire works, as when occupying the interrals between detached works, or portions of them may be conrerted into intrenchments, therefore thes cannot bo dissociated from ficld fortification, in fact they come under the general heading of temporary field fortifications.

Field fortification is perhaps the oldest art in existence, an art probably coeval with the history of man-that is with the history of war, and indeed our oldest records bear witness to its antiquity, whether graven on the granite of EgJpt, or mirrored in the customs of contemporary sarago nations. What changes liave taken place since the Assyrian bing "cast a bank against the fenced cities of Judah," * and yet even now a general of an army, equipped and furnished with the latest results of science. would, like Sennacherib, "cast a bank " against a modern fortress.

Fortitication may, for our purpose, be sufficiently accurately defined as the art of protecting combatants while preserving their fighting powers, and thus, by lessening their adrersaries' capacity to inflict injury, it strengthens, or fortities, the side that employs it. Being

* Ile shall not como into this cit5, nor shoot an arrow there, nor como before it rith slields, nor cast a bank arainst it. - Isaiah, Ixxrii, 33 . 
stationary, fortification is now usually considered defersire, being thus necessarily emplojed by that side which awaits attack, generally (thongh jot always) the weaker side. The attrek, howerer, now, as in old times, cmploys fortification to combat fortification, and is perpetnally Etriving to proluce some movable defence for aggressive purposes, such as of old. were the shiclds of the ancients, the wooden towers that were wheeled up to the walls of the besiegred fortress, or the towers mounted on elephants, and the war-chariots armed with sc5thes. These latter wore really morable forts, from which a formilable plunging fire of missiles conld be delirered at any required point of the battle. Several chariots in line would also make a formidable obstacle analogous to a modern street barricade, with the advantage of being able to adrance, or retire, as required. Later came the Pavésades, a line of shiclds, each shicld or pavois serring to corer two men, one of whom held it whilst the other fought, or the whole line advanced under corer. The heary armour of the middle ages may be said to lave courerted each linight into a fort, * while those who fought on foot prolected themselres with shields or targets.

These old devices for protection are over re-appenring with new faces, and portable fortifications are constantly being recommended for adoption in some form or other. Thus the war-ehariots of the early Grecks and Assyrians may be cunsidered the prototypes of the iron-plated railway battery; the wooden towers and "parésade," of the movable steel mantlets (so ably adrocated in this room not loug ago), $\dagger$ and the missile-catching shields of the musket-proof kaapsack, $\neq$ which has also its supporters both at home and abroad. (See Appendix 1.)

Yet we engincers, as a body, like those of old, prefer going to our mother carth for aid and protection, and to "cast a bank" with a simple spade, rather than rely on moro cumbrous defences. It was in moving earth that tho Roman legions conquered the world, and although our ambition is limited to holding our own, we shall do well to take a lesson from those grand old pagan soldiers, "to whom," in the language of Gibbon, "the use of the spade and pickaxe was no less "fimiliar than that of the sirord or pilum. Active valour may often "bo the present of nature, but such patient diligence can be the fruit " only of habit and discipline."-(" Decline and Fall," \&c.)

In the wars of the middle ages, Charles $\nabla$ and the Prince of Parma appear first to hare restored field fortification to its due prominence in tactics. Charles $V$ attuched to each regiment of Landsknechts a companj of pioneers of 400 men. This company, placed under the command of a special officer, carried with it a littlo pack of tools, and in

* It nas not until the commencement of the 18th century that defensire armour for infautry was entirely abolished in France. $-G$. $G$.

† Sco "Journal of the Rogal United Serrice Institution," No. 1r., page 326, rol. riii.

I This is, I beliere, the only personal portable defence adrocated, with exception of an inrention by a Signor II uratori, of Turin, described as a cuiriss of cloth or canras (which has preriously been treated with somo prepiration). This cuirass is reported to resist easily a powerful bayonet thrust or rerolver bullet fired at balf.aduzen paces. (Report of a Professionil Tour of Oflicers of Royal Artillery in 1868). $-\mathrm{G} . \mathrm{G}$. 
fact corresponded to our present Royal Engineer train. The Prince of Parma had a similar organization, and his army numbercd 3,000 pioneers, who were reinfored as required by workmen taken from the infantry.* Colonel Brialmont states that since the time of the Prince of Parma's famous siege operations, the custom of haring troops specially entrusted with the execntion of field-works secms to have fallen into disuse, snch works, in the subsequent wars of the Princes of Nassau, Gustavus Adolphus, Louis XIII and XIV, being the foreed or voluntary work of the country people. "Historinns aigrec that soldiers " objected to the use of intrenching tools, notrithstanding the laudable " efforts made by their leaders and sorereigns to orcrcome this prejn"dice." $\dagger$ Our own army in the Peninsula was strongly affected with this feeling, thus Sir John Burgogne, in his "Military Opinions" (p. 286), says:-

"Works are not executed by the British in the time they shonld be, " nor with the alacrity with which they are in other services. : I have " known our men (the line) refuse to take ont their gabions and set to "work. I hare myself placed, at different times, hundreds of gabions " with ms own hinds, and then entrated the mon to go and fill them, " but to no purpose."

"In short," says Sir Francis Head, " in the Peninsula these noble "fellows trained to fight in the open, like the generals who commanded "them, disdained either to seck or make cover of any sort:"

$\Lambda$ good deal of this feeling still lingered among our soldiers of the Crinca, but now it is fast dying out, and, with more instruction, we may lope to see it altogether disappear. We havo good grounds for believing this when we note the gallant spirit with which tho 2nd battalion of the Scots Fusileer Guards deroted themselses to fieldworks in the Tower diteh last summer, voluntarily and without any remuneration. When we see such in distinguished corps as this take up the spade and show intelligent interest in their works, we mig consider that the time has passed away when our $\Delta$ rmy, like Gallio, " cared for none of these things."

In the highly disciplined Army of Frederick the Great, (long our model for drill) the soldiers land to work when required, like the Roman legionaries. At Bunzelwitz, for instance (20th August, 1761), for three days and nights one lalf his army $(25,000 \mathrm{men})$ were constantly at work; but it would trespass far besond the limits of this paper to narrate the many instances when intrenchments rapidly thrown up on the ere of netion, have changed the fates of campaigns, and perlaps of nations. This is attested in the Seven Years' IV ar by the fields of Reichenberg, Kuncrsdorf, and the camp of Bunzelwitz; later by Jemappes, Fleurus, Caldiero and Borodino. It is sufficient to note that all the greatest Captains of modern times, Turenue, $\$$ Saxe, Frederick the Great, Napolcon, aud (as firr as his means permitted) the

$\approx$ "La Fortification Improriséc," par $\Lambda$. Brialmont.

+ Idem.

I "The Royal Engiuccr," by the Right IIon. Sir F. B. Ifeat, p. 350 .

\$ Turenne rarels acglected to fortify his camp, corcring it by small detached works, furuished with abatis, \&e. These works (rery similar to shelter-trenches), for 
Duke of Wellington, have declared and testified for all time their sense of the value of fortification in the field. "Field-works," said Napolcon at St. Helena, "are always useful, never injurious (nuisibles) when "well understood." * Our own history illustrates this fact as well as any other. Thus, at a very carly period two of our proudest victories mero gained with the aid of intrenchments. At the battle of Crecy, August Q5th, 1346, Edward III. threw up trenches on his flanks and intrenched his baggage (Foissiart, chap. 126, Hume, rol. ii.). At Poitiers (Sept. 20th, 1356) where 12,000 English stood opposed to 60,000 French, the Black Prince strengthened his well chosen position by intrenchments during the night before the battle (Froissart, chap. 160, Hume, vol. ii.). Since the days of Crecy and Poiticrs, our records of intrenchzuents used in battle are seantier than those of Continental nations. Iet we must remember the great lines of Torres Vedras, before which Massena (Napolcon's spoilt child of victory) vainly chafed and fretted axay lis strength; the intrenchments of Fuentes d'Onoro, thrown up in presence of the enems, by which the same general was again foiled in his purpose; the central redoubt at Talavera, $t$ where Campbell successfully repulsed the French attack; also Hougomont and La Haio Sainte at Waterloo.

Yet these are only noted occasions where field-works hare had a dircet undeniable influence on actions, but how many cases must there have been where temporary fortifications, such as bridge-heads, intreuched outposts, and works of lesser importance may have indirectly contributed largely to influence the operations of the campaign, although unnoted and unknown by the military historian, and perhaps by the Army in general!

Sir William Reid, for example, in a ralnablo paper "On Intrencl" ments as supports in battle" (Professional papers, R.E., rol. 2, old scries) mentions an officer of the 52nd Regiment who, being in chargo of an outpost during the operations of the passage of the Nire in 1813, fortified it so well that the pickets had no occasion to retire nutil they had fired their 60 ronnds of ammunition. "Thus the troops for the "defence of the main central position had full time to assemble (for it "was December, and they wero scattered in houses) and to deploy in "the position," \&c.

Since 1815, intrenchments skilfully planned, appenr to hare woighed heavily in the scales of victory. Witness the Austrians, who made great use of intrenchments against the Italians in 1818, but none at all against the French in 1859, and who again in 1866 at the fatal field of Königrïitz, made little or no attempt to strengthen the villages in front of their line (Sadowa, Dohalitz, \&c.). "The entrances,". says Capt: Webber, $\ddagger$ R.E., "were not even closed; and the strong stone

his first line of infantry, took only a short time to complete. His tools were carried on the crupper by dragoous. ("La Fortification Inprovisée.")-G. G.

* "BContholon," rol. i, pp. 213, 219.

† Sco "Wellington's Despatches," vol. ir, p. 50; also Sir J. Jones's account. No mention of this redoubt by Sir WV. Napier.-G. G.

† "Notes on the Campaigu in Bolenia," by Captain Webber, R.E. Professional Papers, R.E., rol. xri.

YOL XIY. 
" buildiugs which were quito capablo of resisting field artillery, not "eren loopholed." The defences of Chlum extended only to the north and north-west sides, while the Crown Prince attacked it on the north. cast side. Yet incomplete as they were, the $A$ ustrian intreuchments were of great use to them. The Prussians, although attacking, did not neglect the use of field-works, as shown by the strong intrenchments of Dresden, and the defences of Pardubitz.* In the American War, each side made the greatest possible use of intrenchments. Each brigade intrenched itself at the end of the day's march before even cooking their rations. At New Hope Chureh, writes Sherman, reporting on the Atlanta campaign, the enems was repulsed, but having hastily thrown up some intrenchments he maintained himself in his position, and next day we found him strongly intrenclied; thus our attack was fruitless. At Dallas, on the other hand, the Southerners' assault was repulsed, owing to the intrenchments made by Sherman's troops.t

It is noteworthy that the experience the Americans gained in their three jears' figliting led them to multiply intrenchments with great rapidity towards the latter end of the war, as is shown by the battles of March, 1865, round Petersburgh, when the same troops threw up successive lines of trenches during action. Quoting the statement of a Federal Obicer:-

"I'wice had I to change my position in the course of an bour, and " each time I left behind me fu nearly finished line of intrenchments, "so much skill and agility had my men acquired in this hind of "work." ("Lour Years' Campaigning in the Army of the Potomac," by a Federal Oflicer.)

This great American contest prored the adrantnge of corer in all field operations, and the later Bohcmian campaign of $1866^{\circ}$, by displaying the startling effect of the breceh-loading rille, made it obvious that, in future warfare, troops will haro to be kept under corer as much as possible, whether acting on the offensive or defeusive.

Marshal Bugeand said, "If the time for fighting has not arrired, keep soursclf out of range, or corer your troops." Had this been written in the era of rifled guns and small arms, he would have omitted the former alternative, which is obrionsly incompatible with any intention of sudden attack, and deliberate advance under fire from long range is no longer to be thought of.

With the evidence of this before them, the olject of the leading military powers of the Continent became to adopt a method of intrenchment offering extreme facility of execution, and no obstacle to adrance, so that it might, by rapid successive formations, where required, as much as possible rcalize the principle of morable attacling fortitication, without the disadrantages attending all poitable fortitications hitherto proposed. $\neq$

* Capt. Webber cstimates the leugth of line in these defences at $3 \frac{1}{2}$ miles. They were to bo lield by 1,500 infantry and $2 \cdot 1$ guns.

$t$ I hare quoted this at eecond-hand from Col. Brialmont, not laring tho originals. A great many interesting extracts are also giren by Sir F. Head "The Royal Enginecr," pp. 330-335).-G. G.

I Il cu cst résulto une fortificatiou rolaute qui ne constitue paj un obstacle, mais 
Besides these general principles, the consideration of many important details tended to force to the same conclusion; thus, it became crident that, by the introduction of the breech-loading rifle, a soldiel in action can obtain cover, where before he would bavo been insufficiently protected; as, with this arm, he can load while lying at full length on the ground, without changing the horizontal position of his piecc, or betraying limself by any morement. In this position, besides being covered, he hiss the advantage of being able to see an advancing cnems, while the latter can see nothing hut smoke, and of firing with at least five times the rapidity of the muzzle-loading rifle, and with much grenter accuracy, having a rest for his piece on the parapet. Whilo furnished with this prodigiously destructive power, the soldier in the shelter trench will be protected against the fire of infantry, and to a great extent, against that of artiller'y, as we shall see in considering the results of the experiments at Dartmoor last year.

In order to put more clearly before you the opinions of foreign military authorities, I will briefly allude to some late regulations and operations in France and Austria.

To begin with the latter: at the -opening of their disastrous seven wecks' war, the directions of Benedek to his troops were, to "avoid "standing still before the Prussian lines, oppose their defensive firo "by keeping in motion, and charge as soon as you get within 200 "or 300 paces." Since 1866, their military reviers enunciate the doctrine that "the tactics of the future will be entirely confined to "battles of position and firing." ("Tactique de l'Infanterie," by Captain Pontus.) A great rariety of intrenchments have beeu designed and tried by the Austrian military authorities in accordance with this riew.:

The following is an extract from instructions published by the French MTinister of TWar in $1867:-$

"Lses bataillons de la première ligne, déployés et couverts, s'il est "possible, par des plis de terrain, par des abris, par des tranchées, " attendent que l'ennemi soit arrivé î bonne portée pour l'écraser par "des feux ca masse, surtout an moment de la formation des colonnes "d'attaque et lorsque ces colonnes se portent cn arant sur la position. ". . . Aborder de front, en terrain decouvert, une infanterie non "cutannéc, surtout si elle est protégéc par des obstacles ou des courerts, "a tonjours été une opération dangrereuse; anjourd'hui surtout, arec "les armes nourelles, l'arantage appartient à la défensc.

"Une troupe nyant à parcourir 300 à 400 mètres, sous un feu "ćcrasant, quelque brare qu'clle soit, se trouverait exposéo $i$ ètre " détruite arant d'aroir atteint le point décisif do l'action et dans tous "Ies cas arriverait trop affaiblie pour lutter arec succès contro un

un abri pour les hommes.-(Fortification passagere, M. T. Prerost, Chef de Bataillon du Génic.)

* It is veedless to eay that this principle may be carried too far, and result in a loss of all power of mancurring; but it may safely be asserted that in future no bajonet charge should be attempted against troops in position, unles they hare been previously disorganized by fire, in which case the charge would complete the adrastage obtained by the fire, $-G, G$. 
" ennemi preparé ì la receroir et qui au dernier moment prendrait "l'offensive."

Colonel Brialmort relates that, after the American war, the French made a trial of rapid intrenchments at Châlons. "Later on a field day at Vincennes, a division of infantry got orders to intrench themselres in presence of the enemy. The operation was protected by a cloud of skirmisherś. About one-third the effective strength of each battalion got tools. In less than half an hour the whole division was under cover in well made trenches. This experiment was considered very conclusire (trìs concluante)."

We thus see what is the opinion of those in authority in the leading military nations, but it is well that we should pause to consider how far the reasons that have guided them should affect ns, who have our own method of fighting, which cannot be abandoned in mere deference to foreign authority. To do this, we must first glance at the progress that has been made in artillery and infantry-fire since our last luropean war.

In the Crimea, we were opposed by no arms of precision, exeept those used by sharpshooter's from the Russian rifle-pits, so that we must gather our notions of the effect of rifled artillery from foreign experience in war, and from our own experiments. By comparison of results obtained, it may bo ronghly stated that where one shot struck before the introduction of rifled cannon, twenty would strike now at ordinary effective ranges (see Appendix No. 2); but this is far from stating the difference between the rifled and smooth bored guns in their relative effects on bodies of troops. A series of rery valuable experiments was carried on at Dartmoor last year for the purpose of ascertaining the effect of different kind of shell on targets representing infantry in various formations.

The diagram on Plate XXXII, shows the nnmber of lits produced by 15 rounds of 12-pounder rifled segment sleells, at 1,000 yards, on $15 \mathrm{men}$ in single rank, standing, knecling, and in shelter trench. $\dagger$

It would have been better, had time permitted, to have had the results noted at the end of cach ronnd, as it is, I cannot give any correct statement of killed and wounded from this diagram, many having been killed and wounded several times over. Thus numbers 4 and 5 of this diagram have received 25 hits each, the total number of hits being 196. As might be expected, the effect of shell on colnmns is much more remarkable; thus in experiment No. 13, at Dartmoor, 15 rounds of 12-pounder segment slells (with E. time and C.F.S. percussion fuze) were fired against targets representing 6 companies of 27 file each, drawn np at quarter distance behind a slope, so that only the top of the front row was visible. At a range of 1,700 yards, this column was struck in nearly 1,000 places (919 hits). Another experiment (No. 31) was tried on a similar column, partly retired behind the crest of a hill, at 1,670 yards with the same shell (C.F.S. percus-

* "La Fortification Tnproriséc," pp. 16 to 19.

$t$ The lits were copied off the ollicial diagrams, kincly lent me by Captain Alderson, R.d. 
sion fuze), and this time with 15 rounds, the colnmn was struck nearly 1,200 times (1,194 lits).

This alone should be sufficient to convince us that troops can no longer be exposed to artillery fire within effective range of segment or shrapnel without cover:

Turning from artillery to small arms, wo find the progress in the science of destruction sinco our last European war, cren more astonishing. In order to assist us in estimating the difference between the arms of the smooth-bore period and tho latest breech-loaders, I will quote the following extract from the text-book in use at the School of IIusketry (p. 110, et seq.) :-

"The shooting powers of the percussion musket, 18.12, are shown " in a report on 'Lxperimental MLusketry Firing,' carricd on by Captain "MeKerlie, of the Rogal Engineers, at Chatham, in 18.6, which con"cludes as follows:-

" "It appear's by these experiments that,; as a geucral rule, musketry " "fire should never" be opened beyond 150 yards, and certainly not " " exceeding 200 jards. At this distance, half the number of shots " "missed the target, 11 feet 6 inches, and at 150 fards, a rery largo " "proportion also misscd; at 75 and 100 yards every shot struck the " "target 2 feet wide, and had tho deviation increased simply as the " "distance, every shot ought to have struck the target 6 feet wide, " ' at 200 yards; instead of this, howerer, some were observed to pass " "scveral jards to tho right or left; some to fall 30 yards short, and " "others to pass as much bejond; and the cleviation increased in $a$ " "still greater degrec as the range increased. It is only then under " "peculiar circumstances, such as when it many be desirable to bring a " "fire on field artillers, when there are no other means of replying to it, " "that it ought erer to' be thought of using the musket at such dis" "tances ns 100 yards."

After the interesting paper read here, and published in the Jonrnal of this Institation (The MIartini-Henry Rifle, by Capt. V. D. Majendie, R.A., No. lr, Journal of Royal United Serrice Institution), it is unnecessary for mo to sny much abont brecch-londers, but it is curious to compare these records of Old Brown Bess with some of the achierements of that latest, deadliest combination, the Mrartini-Henry. Captain Majendio gives the following as averages of 5 targets of 20 shots each with this arm :-

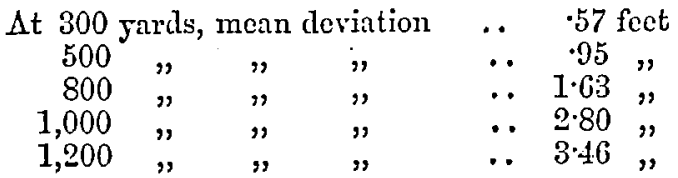

As regards rapility, a rate of fire, without aiming, of 20 rounds in 18 seconds, equal to 25 shots a minute, has been obtained.

This will make battles somewhat different to what they were when a man was safe at 200 jards, and when, as military writers have estimated, not more than 1 ball in 10,000 attained its mark, though of course the practice of the rifle range is not that of the battle field, 
where allowance must be made for liaste and excitement, exaggeration of distanees, \&c. Mlore experiments, especially in rolley firing, which the tacties of the day prescribe for breech-Ioaders, will haro to be made before the relatico ralue of the Martini-Henry to its predecessors can be accuratel 5 determined; but it is erident that we havo got a weapon of ronderful power, especially in defensiro,positions.

Besides this, we hear of a new arm of most formidable character, which has already been introduced into the French serrice, "The Mitrailleur."

In a raluable paper on this subject (Journal of Rojal Lnited Service Institution, No. lvi), Major Fusbery informs us that the MontignyMitrailleur (which may be described as a gun composed of 37 rifle barrels) will send 414 shots per minute with great accuracy up to 1,200 Jards, and that withont requiring to relay the gun after once ascertaining the distance. In conclusion he remarks:-

"Deliberate and continuous movements, in face of either artillery or " infantry, will become more and more impossible, and we shall have to "prepare for short and rapid concentrations from extended order, or "sudden rushes from cover, natural o" artificial," \&c.

Captain MIajendic, R.A., thus concludes lis paper on tho MartiniHenry:*-

"What wo have now to do is, to seek an efficient and ready means of "defence for our soldiers against these terrible arms of precision, " which can ponr forth such an amazing stream of fire, consuming all " it touches. Tre may, by the establishment of a system of field " intrenchment, do much to afford cover and concenlment to our "men," \&c.

These remarks from Officers who have been specially deroting themselves to the study and development of arms of precision, are well worthy of our attention.

$A$ few trials were made at Dartmoor of the effect of artillery firo upon hasty intrenchments, or shelter trenches thrown up by infantro, in from 18 to 24 minutes (see Figs. 9 and 10, plate XXXIV), dummies being placed behind these intrenchments, so as to represent infnntry kneeling and firing. It is unfortmate for our purpose that no experiments were tried against dummies in the same position with. out shelter trenches. However, by counting the hits on the official diagrams that would haro struck men standing or knceling without cover, or firing from shelter trenches, $f$ we may arrive at an approxi-

* "Journal of the Rogal United Scrice Institution," No. 1s, p. 350.

+ For this purpose, I constructed diagrams (on a scale corresponding to the large photographs of a single rank of 15 men standing and kneeling, as exhibited in lecture room) of the targets, representing the frout mans in experiments No3. 2 and 4, on tracing cloth, applied theni to the photographs, and counted all hits on the figures. To obtain the probable results on the Eame kneeling rank if protected by a shelter trench, the ground lerel (or foot of the target) was taken at 15 inches (the height of the parapet) below the muzzle of the rifle, then all "throughs" mere allowed to count for 6 inches from top of parapet; below that, only entire shells which would hare gone through the parapet. Abore the line of the crest, of course all hits on the figures were counted. Diagrams in Dlate II show the relatire number of hits standing, hoceling, and in treuch, with shrapucl at 1000 yards.-G. C. 


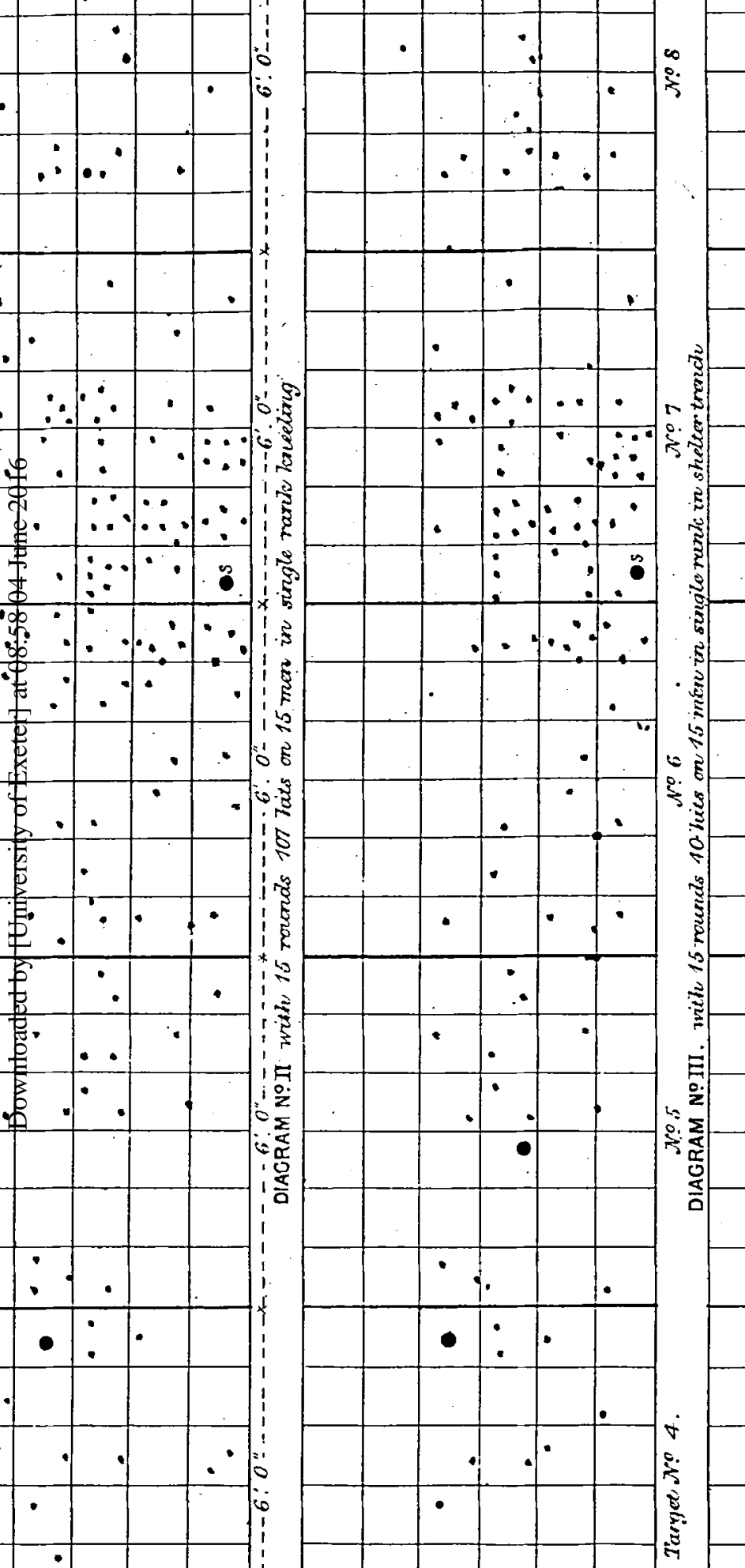




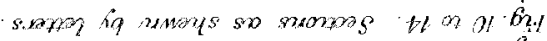
to monas 6 67t

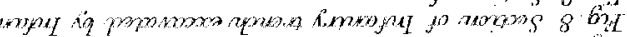

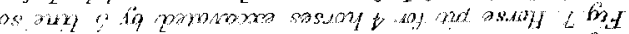

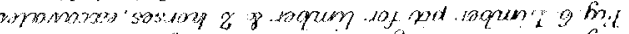

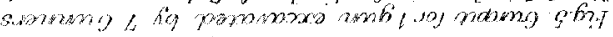

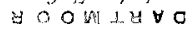

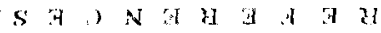

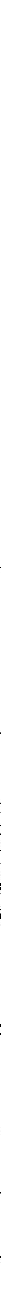

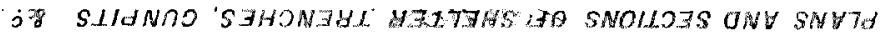

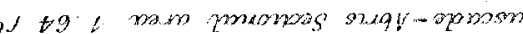
$696 \%$ won s.

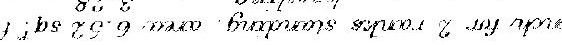
1 
mate estimate of the number of hits saved by the shelter trench parapet. In order to make the comparison, I have taken the lits on targets 4 to 8 only, giving a front of 30 feet, the length of the 18 minnto shelter trench.

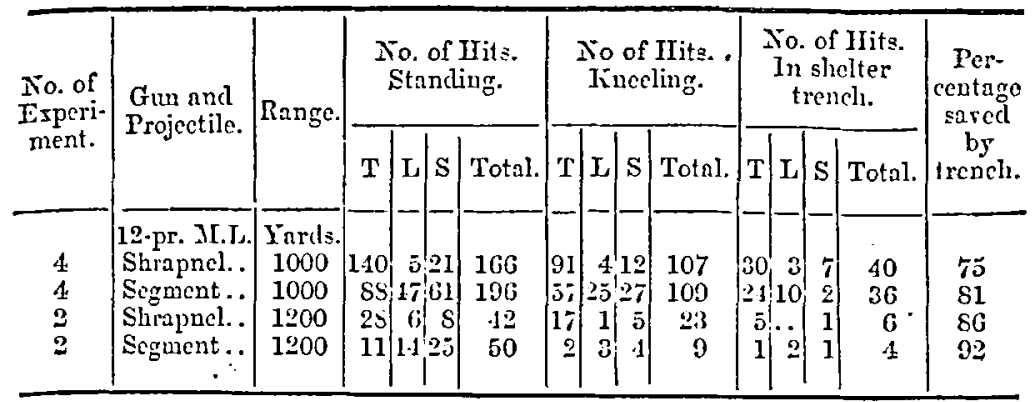

This gires, as the arerage percentage of hits sared by the trench, S3!, a result very closely coufirmed by comparison with the actual practice at the shelter trench on the 10 th $\mathrm{July}$, thus :-

Experiment No. 2, 15th June, 1869. Against targets 4 to 8 . IIits

Ilits. $\mathrm{p}^{\mathrm{Cr}}$ Range.

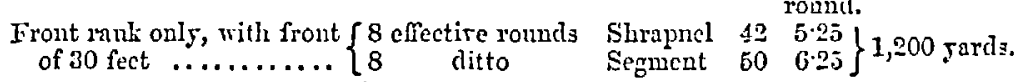

Experiment No. 2, 10th Juty, 1869. Against sheltcr trench.

IIits. per: Range.

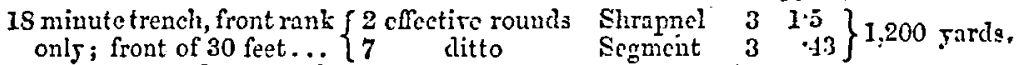
Percentage sured b5 trench mith Shrapnel ............... $\tau_{2}$

Ditto dito Segment $\ldots \ldots \ldots \ldots \ldots \ldots . . .03$

Aremge perecntage sared by trencla $\ldots \ldots \ldots \ldots \ldots \ldots \ldots \ldots$. 82 ?

Wc arrire, then, at this result, that for erery 100 hits on a single rank of men standing upright there will only be about 18 hits on the same number of men occupying the same front if firing over the parapet of a shelter-trench. Had wo the means of making a similar comparatire statement of the number of hits received by a line tro-deep, first standing and then intrenched (front rank knecling and rear rank lying, as shown in Fig. 1, plate $\mathrm{XXXV}$ ), we should of course obtain a much larger percentage of hits saved. As it is, I feel convincel that the suring shown by the abore calculation very much auder-states the protection afforderl by shelter-trenches against artillery fire." Thus, the supposition

* The Committeo dirided the hits into shots, or splinters that reut throrigl the targets ("through" "), others that lu:tged ("lodges"), and others that only dinted or struck ("strikes"), and onls tro-thirds of the latter" were allomed as hits. I hare 
in theso diagrams, and in the trials against shelter-trenches at Dartmoor, is that the occupants of the trench would almays be in the act of firing over the parapet, whereas (since no artillery Officer would, if he could help it, bring his guns within rifle range) they would more probably be lying down under cover. (See illustration, Plato XXXVI.) Besides this, the usual condition under which guns would come into action against shelter-trenches rrould bo that of firing at an unknown range, and considering that the difficulty of secing the trenches at all at Dartmoor from ver'y moderate ranges was so great that flags lind to be put up to show their position (although no previons attempt had been made to conceal them by branches or lieather), I cannot believe that, eren with Captain Nolan's telemeter, it will be an casy matter to ascertain their distance. The diffeulty of striking these low carthworks yas indeed shown very clearly by the experiment on July 9 th, when trelve rounds of shrapnel aud twelve of common shell were fired with the intention of burstingt them in the parapet of the rench, "but," as stated in a report, " none could be made to strike in exactly tho "proper place, notwithstanding which, the practice must be considered " as very good, as an error of one or two feet in elerition would bo "sufficient to account for the distance under and over at which the " shells struck." **

Thus, then, twenty-four ronnds of delibernte practice, by first class artillerymen, knowing the range, and with nothing to disturb them, produced absolutely no effect whatcror on a shelter-trench at 1,500 yctirts.

In order to ascertain the value of shelter-trenches as a protection against musketry, it would be very desirablo to have somo experiments made to ascertain the relative efficiency of two bodies of infantry, one behind a shelter-trench, and tho other adrancing to the assault. At present all wo know is that any parapet orer twenty inches thick is proof against the best rifle. The following statement has been supplied to mo by an Officert who has made many expcriments with the new rifle, "Snpposing an attacking party 400 strong has to advance against " 100 men, armed with Martini-Henry rifles, and well sheltered, 50 to " fire and 50 to proride them with ammunition, time adrancing three " minutes, by the cul of the second minute there ought not to be a man left "staneling."

As this paper will not have the advantage of being discussed at this mecting, I propose, before proceeding further, to notice the principal objections that $I$ think can bo made against the uso of intrenchments in battle.

$\$ 1$. "The use of shelter-trenches is contrary to the spirit of modern

preferred counting erergthing as a hit. Tery little suffices to disable a man, and a man disabled is for military purposes better than a man killed, as he takes off other men to attend to him. Sccording to French experiments, a ball penctrating 16 millimetres ( 63 inches) into deal will disable a man.

* Report on Dartmoor Experiments, by Licutenants Day and Cockburn, R.E.

+ Capt. Drake, R.E., Musketry Instructor. Sce Appendix No. 3.

+ These first two objections are borrowed from Captain Charrin, of the Delgian Arny, proposer of a musket-proof knapsack. (Sco "Spectateur Mrilitaire.") 
Jarmal ES Instidution
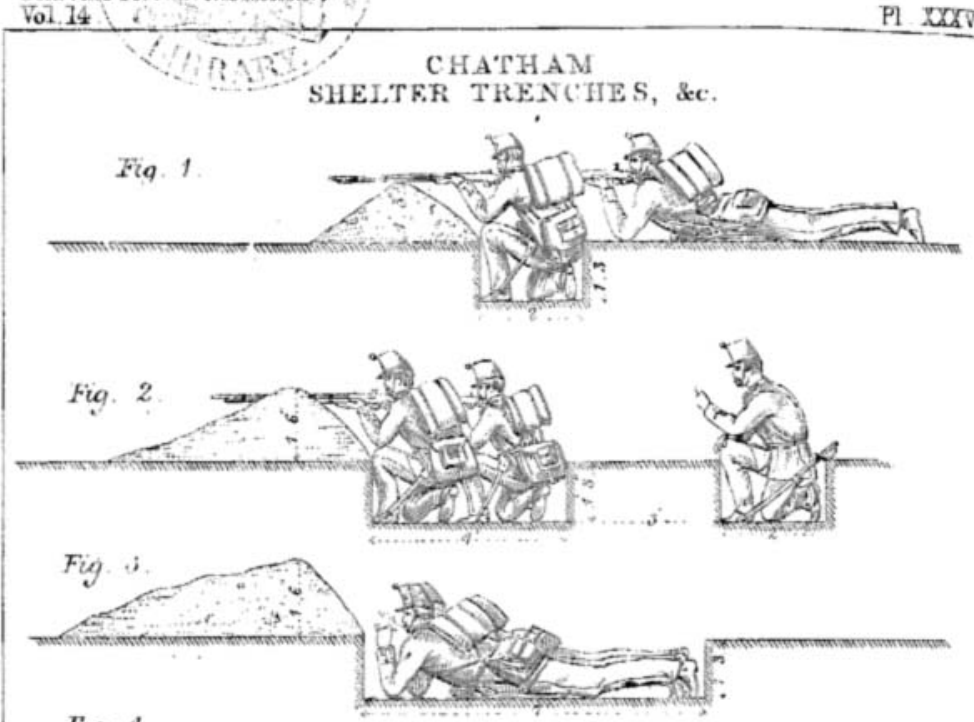

Fug. 4. Shelter Trench for I Company

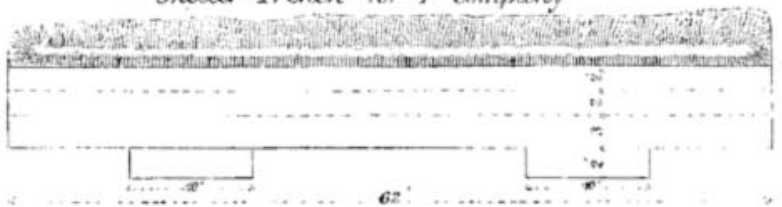

Changer Pils
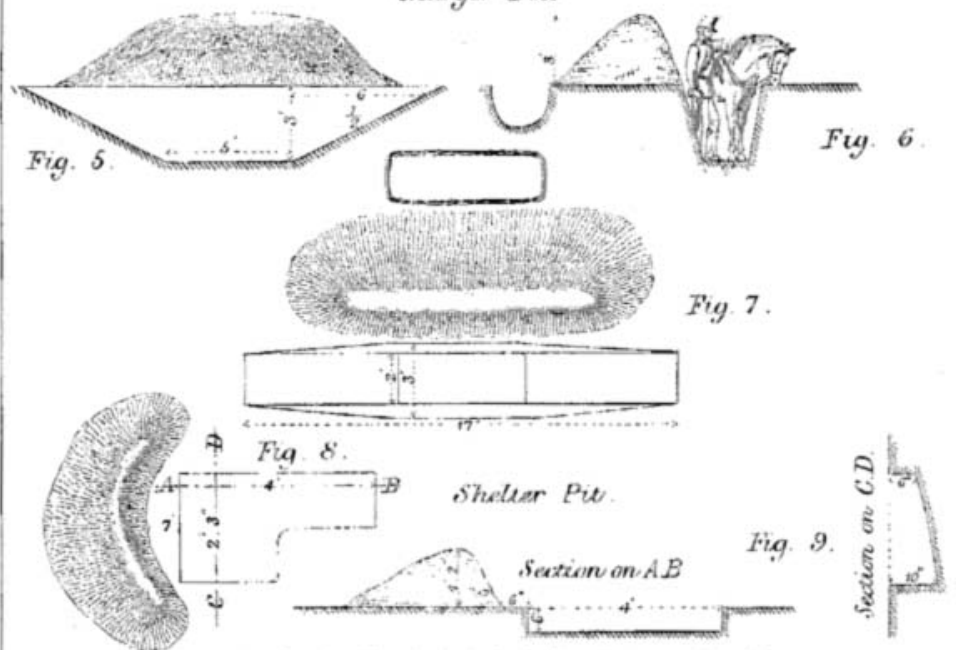

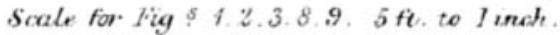

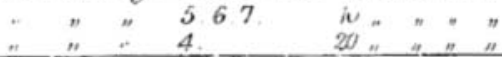




\section{BATTALION LYING DOWN IN LINE.}
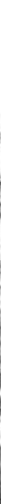

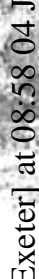
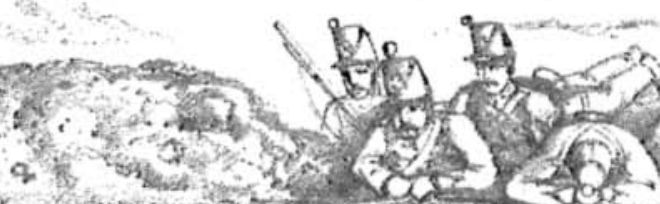

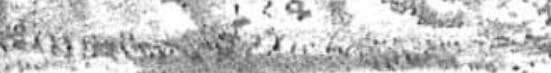

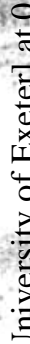

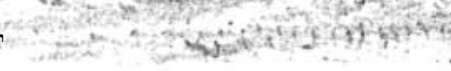

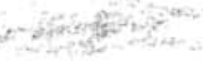

The 1 inges

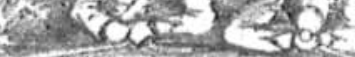

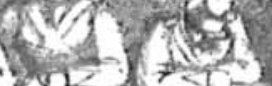

$1 \times 12$

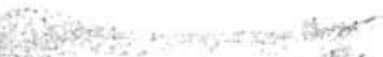

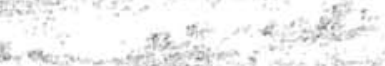

cêे

seines.

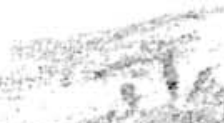

nutesition

3

$\frac{8}{8}$

$=-1$

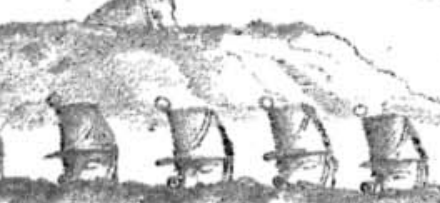

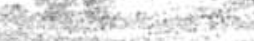

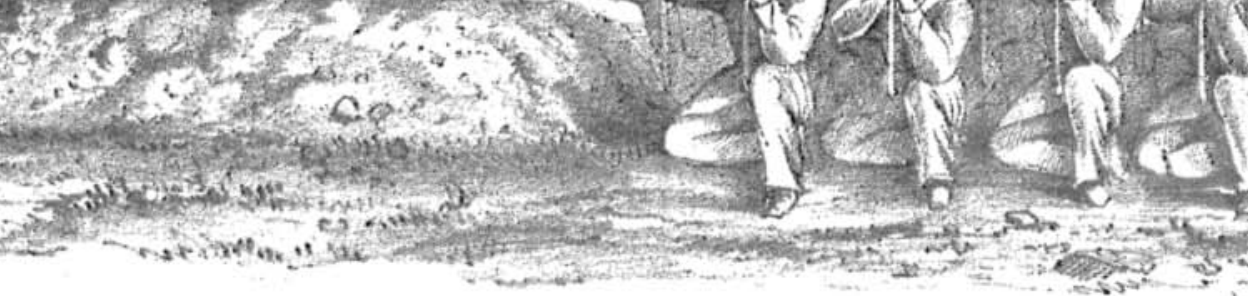

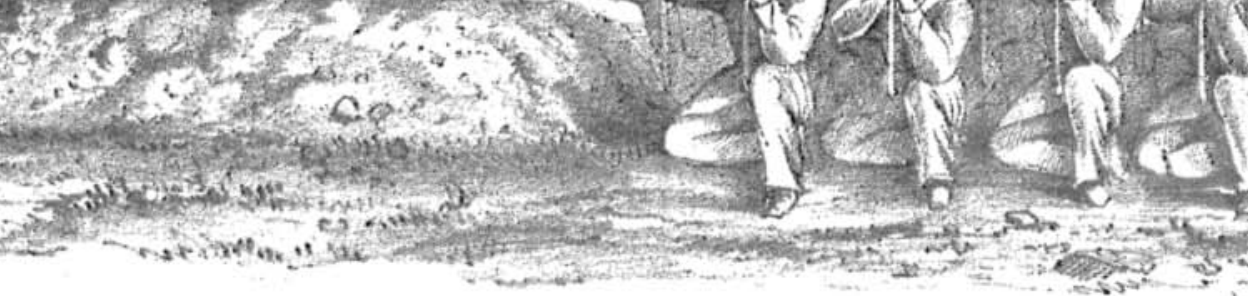

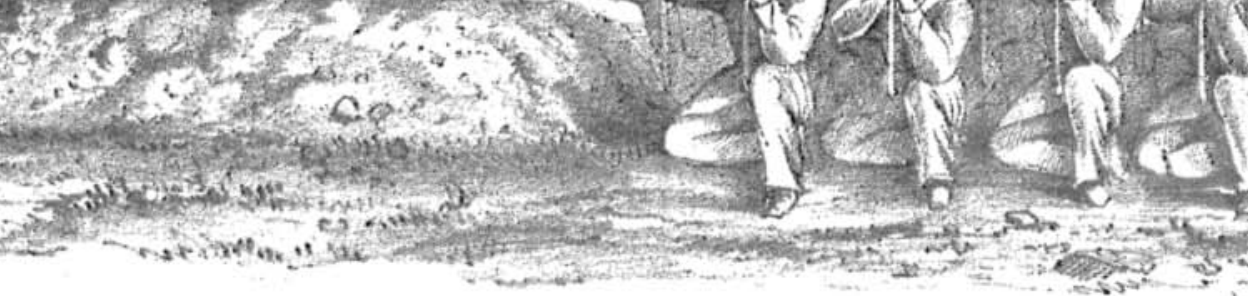
TER TRENCH

\section{BATTALION IN ACTION IN LINE.}
IN THE OPE 
" tactics, which requires the utmost flexibility and rapility of wove"ment."

Reply.-Flexibility is quite compatible with the use of shelter-trenches, which should offer no impediment to the free transit of troops; rapidity of morenent is obriously not affected by them; continuous rapid movement certainly is incompatible with their usc, but unresting rapidity is imprecticable, and to attempt it wonld be worso than useless before rifled guns and brcech-loading rifles.

2. "The ground is not always fit for intrenchments, the Army may " find itself in a marshy plain, or amid shifting desert sands, or worse "still, on bare rocks."

Reply. - This mas happen, but even in such exceptional cases the troops will be all the better for having been taught to cover themselves; among rocks they will probably not need other than natural cover.

3. "Trenches demoralize the soldier, who learns to crouch bchind " parapets and to fear exposure."

Reply.-On the contrary, they demoralize the soldier who has to attack them by adding to his difficulties and losses. As, however, this is a stock argument against intrenchments, I propose replying to it at greater.length.

Does training a soldier and making him more ablo and intelligent demoralize him?

Those who hold it docs, are consistent in believing, that teaching him how to protect himself, demoralizes him. It has been said by many , that the trenchwork before Sebastopol demoralized the soldiers; that they lost the dash and daring of British troops and cluug to parapets when they should have gone forward. As one who served in the trenches throughout that siege, I wish to gite my testimony against the riotion that the trenches demoralize the men. I believe that thoso who origrinated these sayings hare generalized too much on individual cases, perlaps of recruits who iever were soldiers, or of old soldiers who never were good ones, and that they have hastily attributed these shortcomings to the trenches. Sickness and suffering, disappointment and doubt, demoralize men, and all these onr soldiers had to bear up against during that long siege. But we Engineers cannot admit that the trenches demoralized them. What troops had so much trenchwork as our Sappers, and who will say that they ever shrunk from exposing themselves when required? It is unnecessary to gire instances of this, as they were doing it erery day and night of tho siege, when "follow the Sapper" was the ovder of march. I would not lave noticed the Sebastopol illustration, but that I know it is often brought forward, for after all what comparison can there be between the trenches of Sebastopol, where men did duty for nearly a year, always more or less under fire, usually with rery little chance of returning it, and troops lying for a short time under cover during action, either engaged, or awaiting an order to adrance?

An objection lias been put to me in the form of a dilemma, thus:-

4. A battle is either fought offensively or defensively; if the former then shelter-trenches are useless, if the latter, unnecessary, the best defences being detached worts like those of Torres Vedras. 
Reply.-This assumption is incorrect, as unless the forces are very unequal, no battle can be purely offensive or defensive. All authors antee "that defensire positions are best maintained by offensire actions". (sce Sir Wm. Reid's paper), or, as the French express it, "Combat " défensif arec retour offensif." "Les armées offensires elles-mêmes " no sont pas dispensées do se fortificr; car elles ne sont pas toujours " ct cn tous lienx supćrieures, et cllcs ont ì prendre quelques pré" cautions sur leurs flanes et sur leurs derrièrcs...... elle se dégarnira " en certains points, se contentant d's obserrer son ennemi, pour agir " ailleurs arec la meilleure partie de ses forces.... . clle ne doit pas " négliger...... de courrir par des retranchements légers, ses grand " gardes et ses arant portes; la prudence reut nussi qu'elle protége "également, par quelques postes retranchés, ses derrières et sa ligue " d'opérntions." (Noiset's Fortification.) The improvements in arms of precision (especially musketry) luave made the defence so much stronger than the attack, that the principle so prophetically enunciated by Napolcon must now be acted on, that tactics shonld be based on fortification. On this principle, no Army in a defensive position will in future bo attacked without previous connter-battering from guns protected by earthworks, while the troops of the first line are kept ready for the assanlt in a parallel of natural or artificial corer.

Tith reference to the character of the rorks of defence it will, I apprehend in future warfare, be found inadrisable to concentrate troops in detached forts without bomb-proof protection or corered commanications (which hasty intrenchments cannot have). Natural corer between the forts must, therefore, be improred (commencing with mere shelter trenches) as much as possible, and the main body of troops kept in line in these intervals when most capable of taking the offensive.

At this point the question previously put may be answered, riz.: Is the use of shelter trenches compatible with our English mode of fighting?-Yes; because it is peculiarly well suited to our line formation, and therefore our troops would adapt themselres more casily to it than those of Continental nations who fight in column. To our troops, no chango of formation would be needed in an adrance from the line of trench, and to them there wonld be no change of tactics in receiving a charge in line.

To some, perhaps, it may still appear unmanly, or un-English to bo under corer; but I can only allude to this feeling as a mischierous piece of sentimentalism which ought to be rooted out. Let us not in anj future war sacrifice our men to any such pacrile considerations as these; let us not again merit the reproach of the historian of the Peninsular campaigns : that " in the beginning of each war, Lingland "Las to seek in blood the knowledge necessary to ensure success."

We hare now to consider what form of trench is best adapted for the field. Fig. 1, plate XXXIV, is the profile recommended by the French; it is large enough for two ranls and gires cover to men firing standing. Fig. 2 is for two ranks kneeling; in both, the parapet is thick cnough to resist musketry.

Slielter trenches of this kind havo been thrown up in the French 
camps in 25 minutes in ordinary ground, and in 35 minutes in rery diffienlt soil. In July, 1868, the Italian Army, encamped at Fojano, made shelter-trenches with untrained troops. $150 \mathrm{meu}$ in 25 minutes made a trench of 93 metres length in stiff clas, aud later $128 \mathrm{men}$ made in similar soil a trench of 100 metres in 30 minutes.

The Austrians have made many experiments in shclter-trenches. Fig. 3 shows the profile recommended by them." Fig. 1, plate XXXV., is the Chatham section for a shelter-trench as giren in the Field-book of Instruction. "Such a trench can bo excented by men with their " accoutrements on, distributed at from 4 to 6 fect interrals in from " 10 to 20 minutes. This is the smallest trench that is of any use and " will afford corer to two ranks, one knecling in the trench and ono " Jying in rear of it." This trench can bo widened, as shown in Figs. 2 and 3 , or men skirmishing may make shelter pits for themselves, such as shown by Figs. 8, 9, plate XXXV. This may be made in from 2 to 4 . minutes with rery little practice by one man of a file of skirmishers. The same thing is practised by the French (cmbuscade-abris). See Fig. 4, plate XXXIV. Branches, bundles of underwood, \&e., may be used for screens. Charger pits may sometimes be necessary, such as shown by Figs. 5, 6, 7, plate XXXV. This can bo made by four men in half-an-houl.

Plate XXXVI is a photograph from a spirited drawing by Licut. Conder, R.E., showing a detachment in line both in action and at rest, with or without protection. The adrantage of the parnpet is too erident to need further remark.

Figs. 5 to 14, plate XXXIV., show plans and sections of the shelter trenches, gun and limber-pits used at the experiments at Dartmoor, already referred to.

Two gun-pits were made, each for one gun and its detnchmentexcarated by seven gumners in one hour. A rouglhly-constructed model of a ficld-grm, and sis dummies to represent the detachment, were placed in each.

Experiment 1 was with 12-pounders at 930 yards. Results: with shrapnel, 2 lilled, 2 wounded, gun and carriage untonched; with segment, 2 killed, 1 rounded, gnn and carriage marked by splinters.

Experiment 2 was with 12 -ponnders, at 1,525 yards $; 12$ rounds were fired with each. Results : with shrapnel 2 killed, carriage injured; with segment in gun-pit nil; but, in limber-pit, limber much injured, horse killed. On the 9th June, 12 rounds of segment at the same range were again fired at this pit rith no results.

This practice seems to have led some Artillery Officers to the conclusion that gun-pits are of little or no uso; but $I$ would submit to them, for further consideration, that the conditions under which these experiments were conducted were not precisely those of war. Thus, the cxact range was known, the guu-pits were isolated works, so as to show a distinct mark to the gunmers, whose aim was further assisted

* Taken from Col. Brialmont's pamiphlet, "La Fortification Inproriséc."

t It will be obserred that this draming is taken from a rely commanding position, in full riew of the parapet of the charger pit, which would otherwise be lardly risible orer that of the shelter-trench. $-\mathrm{G} . \mathrm{G}$. 
by small flags planted in the parapet, though it is true they lad not the flasls and smoke of answering guns to guide them (if, indeed, that is a guide bejond point-blank range). Then the gun-detachment being dummies were always standiug at their guns instend of raming in occa. sionally and "liugging the parnet,", as sensible live gunners would do, betrreen the rounds; at all erents, to test the value of the protection, some similar dnmmy gun-detachment ought to have been placed in the open and fired at from the same range. In 1862, a trial of this kind was made by the Ordnance Select Committee at real guns and carriages. Thes report the result of 12-pounder segment shclls at 1,000 yards as follows:- "The carriage of the gun fired at with segment shells was "severely cut up, one wheel being completely destroyed." Later in the year, they renewed the experiment at 600 yards, this time provid. ing the gau with a dummy detachment. The results of firing with the 12-pounder gun was then as follows:- "All the detachment "were struck, sereral of the dummies were cut to pieces; car" riage described as being lmocked to pieces; portion of a whecl " carried 30 yards to the rear." It is therefore evident that bad as the inside of a gun-pit may be under artillery fire, it is better than the outside; besides, it must be remembered that gunpits are also intended as a protection against Infantry fire, and although unfortunately no experiments with small arms were made at Dartnoor, jet we know that a rifle bullet will not penctrate more than 12 inches of carth at 220 yards, and that the exposure of gunners firing from a gun-pit is certaiuly not one-quarter that of the same men uuprotected. By the experiments at Hythe in $\mathbf{1 8 5 6}$ with rifle practice against guus and dummies at 800 yards, it was shown conclusively that artillery wonld be beaten off the field by infantry, armed eren with the Enficld.

A similar experiment was tricd in Austria a short timo since, when a company of infantry of 200 men opened volley fire on a field battery (8 guus), having dummy men and hor'ses, with the following results:-

At 1,000 yards-126 lits ont of 1,100 shots, or $11 \frac{1}{2} \mathrm{per}$ cent.

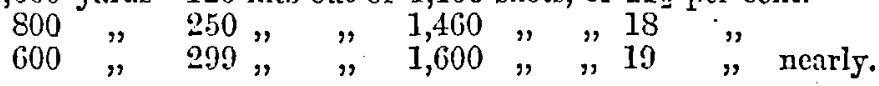

Thus at 1,000 jards they would have made 115 hits per minute, at the deliberate rate of fire shots per minute, or sufficient to disable the entire battery in one minute.*

The following is a brief account of the method of forming sheltertrenches as practised at Chathan in accordance with the drill instructions now preparing for issue:-

The battalion having been formed in quarter column on one flank of the tools, the rear ranks file out, each man taking a tool as he passes tho markers, who distribute shovels to all tho odd, and picks to all the even numbers. On the march the tools are transferred from one rank to another, to relieve the men, but on arriving near the position of the proposed shelter-trench, tho tools are again taken by the renr rank,

$\because$ Sce also an interesting paper on this subject by Lieut. Walkey, R.A., in Fro. ceelings of R.A. Institution, December, 186G.-G. G. 
who form the treuch, while the front rank open firc or lie down, or remain standing in adrance, according to circnmstances. The markers are then ordered out and placed along tho intended line of trench, nsually following the contours of the ground; the rear rank in the mean time form two deep, pile arms and prepare for work. The line of trench may then be marked with picks or tracing tapes. About threc-fourths of the odd numbers of the rear rank then extend at double arm distance, touching each other with extended hands, dressing by the markers, who extend one arm. The odd and even numbers then work together in pairs, cach pair occupying about $5:$ feet of ground, and making the trench 2 feet wide and $1 \frac{1}{4}$ feet decp, only one man working at a time. To place the men thus, takes usually about two minutes from the time of arrival on the ground to the moment of commencing work. The remaining quarter of the rear rank are employed on the trenches for the officers and supernumeraries, and on the charger pits.

The Austrian method is to place two men to every 3 Austrian feet run (about 3 feet 8 inches English), thus employing two-thirds of the number of men to be covered. This must eramp their working powers, being too confined. The French place one mau per metre (abont 3 feet 4 inches), and thus employ one-third the number to be covered.*

Colonel Brialmont proposes forming the battalion with double files, carrying shovels, alternating with single files carrying picks; halt them at four paces from the site of the trench, and open the ranks, laying arms and packs on the ground; the front rank then adranees with tools, cach group of three establishes itself in a portion (atelier) of 1.80 metres in length (corresponding to the space occupied by three men in the ranks, 5 feet 10 inclies, or $23 \cdot 72$ inches per man). Two of these men liave spades, the third a pick. This latter places himself between the two first and in rear of them. After 10 minutes' work, the mon of the second rank who are lying down behind their arms, relieve those of the first rank. The intrenchments are thus executed along the whole extent of the front with the co-operation of all the men. Ono half of them guard the other half, and in less than a minute, in case of unforseen danger, the battalion would bo under arms.t

As may be seen, therefore, the main points of difference between our method and that emplosed on the Continent are-1st, that wo nse equal numbers of picks and shovels, while they use only one pick to cvery tro shovels; and, secondly, that they make no provision for supernumeraries, \&c., who, they say, can enter the shelter-trench with the men, or sit on the reverse of it when large enough.

With reference to the 1st point, we find it best to provide equal numbers of picks and shovels, our men always working by fles or. pairs, and in the shelter-trench, as only one works at a time, he has both pick and shorel at his command. As regards No. 2, it is considered better for purposes of supervision and discipline, to have distinct positions for the ofticers, \&c.

* Sir workmen, four shorels and tmo picks, to $5 \cdot 20$ metres length ( $=17 \mathrm{ft}$. nearly) $=\mathrm{a}$ space of nine filcs, or $18 \mathrm{men}$, cach file in the ranks occupging about 58 ccnitmetres (22-83 inclies).-G. G.

† "La Fortification Improriséc." 
It would be beyoud the imposed limits of this paper to enter into any description of the appliention of shelter-trenches to the field of battle. Here the engineer aud tnctician should combine, the line of front should be in extent cxactly proportioned to the number of troops; in fact, "the defences should lit like a garment on the body "of the Army," * loose and free where action is required, close and thick where protection is wanted, in other words, the field should be divided into offensire and defensive portions. In fact, fortification, here on the battle-field as elsewhere, should be cmployed to economise men, and in this it may be compared to those mechanical inrentions which are used to economise manual labour, and especinlly to such as store up the accumulated results of labour. Thus the fortified posts of a line of battle may be likened to the fly-wheels of a shaft, they are " magazines of power," so that the force espended on them at the beginning will be recorered again at the end.

The preparation of a field of battle, as thus indicated, pre-supposes choice of cround and time for exccution. For instance, supposing the army came into bivonac on the position cliosen the afternoon of the day preceding the expected action; they rest, if tired by the mareh, while the General and his Staff reconnoitre and decide on the works to be thrown up. Then, in half a hour before dark, the shelter trenches could be completed, while the more important works of the defence could be executed by skilled troops during the night. $f$ It will be a great advantage in these hasty intrenchments over moro solid works, which take longer in execution, that the enemy will necessarily be in ignorance of their exact strength and position. On the other hand, the General of an army acting on the offensive, will make use of sheltertrenches according to his intended tactics and what he expects from his encing. 'Thus he may have to intrench an exposed flank, or a part of his line denuded of troops, which are massed for attack in another part. His first line should always be under corer, uatural er artificial. Large openings, or intervals between the trenches should bo left, suflicient for grand divisions of infantry ox squadrons of caralry on the flanks of brigades, besides the'battalion intervals, which might be half those of the brigades. The lines of shelter-trench should be straight or following the contours of the ground-not broken into flanks. In that remarkable paper written 30 Jears ago, on "Intrench"ments as Supports in Battle," + from which I have alrcady made extracts, an account is giren how the slight rorks at Fuentes d'Onoro, thrown up in presence of the enemy, foiled the French attach. MIassena explained his failure by representing " the enemy, drawing to their " assistance all the resources of fortification against an attack by main

* "Passend ric cin Lleid am Förpcr der Armee."

$\dagger$ On the defensire parts of the ficld the shelter-trenches slould, if time permit, have the excaration on the front side, su as to ofler a grcater obstacle to the enemy. Sec paper by Sir J. Burgogne on Ilasty Intrenchments, rol. xriii., P. P. R. E.G. G.

\# By Colonel Reid, R.E., tho gifted author of the "Law of Storms," \&c. Sec Sir F. B. Head's humourous, but highly appreciatire notice of Sir William Reid, in "Rojal Engincer," pp. 298, 299. 
"force."-(Times newspaper, 29th Mray, 1811.) "But," says Sir Wrilliam Reid, " howerer much erery man in that arms, at that " moment, might have been desirous of availing himself of all the " resources of fortification, such was not within lis reach; for it is "supposed that this portion of the Army had no other intrenching "tools than the few carrice by the regiments for the purpose;" and " there was but one engineer officer present."

The question of tools will lave to be considered in connection with this subject; the scarcity and want of them was probably the principal reason why field fortification played such a secondary part in our Peninsular campaign, as the practical sagacity of the great Duke secms to have impressed him with an ever-growing couviction of its importance, of which many instauces could be giren from his late campaigns. $\dagger$

Sir W. Reid relates that after the battle of Toulonse, the British Army was to have been intrenched. "Strong country houses wero "fortified at about every 600 or 800 5ards from cach other, etc.

" in rear of the intervals straight trenches were just about to hare " been commenced when the enemy's army retired." Again at the operations of the passage of the Nive, intrenchments were used. It is indeed pretty certain that the Duke of Trellington contemplated intrenching the field of Watcrloo, as is shown by a memorandum of his (dated 22nd September, 1814), on the defence of the Netherlands, quoted by Sir Francis Head ("The Royal Engincer," p. 326), and the same authority states that an order was giren on the ere of the battle (too late for accomplishment) to a company of Royal Engineers to march to Brainc-la-leud, and there make an intrenchment for the right of the position of Waterloo.

We learn also from Napolcon's M[cmoirs, that ho expected to find the Allies intrenched at Waterloo, and especinlly charged General Haxo to reconuoitre and ascertain this point. Yet at the battle of Waterloo (as elsewhere, under the Duke of Wellington), although the troops were not intrenched, the principles here adrocated of kecping troops under cover until the time arrires for adrancing, were carried ont as far as was possible with natural corer only.

Quoting again from $\mathrm{Sir}$ W. Reid:- "It was the custom during "the late war for the British Infantry, when they occnpied a de"fensire position, to draw up just behind, and under corer of the " slope of a ridge, when there was one, from whence the lines rere "brought forward to charge at the proper moment." They were also taught to take advantuge of any natural or artificial corer they could find, thus at the battlo of Waterloo, the first check to the French attack on TVellington's left centre was from three companies of the

* One mule per regiment for intrenching tools. G. O. Abrantez, 19th June, 1800.-G. G.

$\uparrow$ There is difficulty in citing instances, as the cases where intrenchments weje used in the battles of the Peninsula appear to hare becu imperfectly recorded and preserred. Sketches by Sir Philiip Bainbrigge (who was Assistant QuartermasterGeneral in the Peniusular war) exist, showing that not merely parapets and ditches, but long lines of cocer, following the contours of the ground, Were constructed by the Duke in Spain.-G. G. 
95th Kiilles, who were posted in a sandpit and along a hedgo in rear of it: Kempt's Brigade lined the hedge of the Warre road, fired a volley on tho French central columu (which was in the act of deploying), and then made a charge, but was delayed and somershat disordered by the difficulty of getting through the hedge. The 79th Highlanders, in particular, suffered greatl 5 , and here it was that Picton was killed.* 'l'his shows elearly the neecssity that the cover obtained should be of a nature not to obstruet the advance of the troops. Hence the liedges and ditches of cultirated districts are rarely suitable for offensire defence without special preparation; and although natural corer, such as that afforded by gentle slopes and undulations, will continue to be extremely raluable, it will be found in most cases insuflicient to protect troops from the explosive projectiles of modern rifled cannon, as was elearly shown by the experiments at Dartmoor (already referred to), against columns partly concealed by rising ground.

Now, at the battle of Waterloo, we know that about 1.30 p.m., Napoleon adranced 10 batteries (74. gans) to within a range of 600 to 800 yards from the English line to support the attack on Picton's division, already referred to. Siborne says, "The nature of the ground "permitted the batteries to play orer the heads of the three adrancing " columns of French infautry, and great was the havoc in Picton's ranks." -(Siborne's Waterloo.) Supposing the battlo had been fought with the arms and experience of the present day, it is certain that Napoleon would not hare advanced his guns within 800 yards, as they could make haroe and destruction enough at double that distance. It is indeed awful to consider what would be the effect of 71 gans acting on unprotected columnst of troops, when we cousider the practice at Dartmoor. By experiments 13 and 31, as already stated, a column of targets may bo hit orer 1,000 times with 15 ronnds. Allowing now that one-half of these were caused by "throughs," still 2 rounds per minuto from 74 guns would inflict nearly 5,000 hits per minute; sufficient, one would think, to have cleared Picton's division off the face of the earth in ten minutes. But, it may be said, our guns wouldn't hare been idle all this time, the French would hare suffered at least as much as we should. True, on the fair fighting principle of equal exposure, but supposing the French had intrenched themselves, as they did at Chalons, the other das-supposing that Napoleon had deroted one hour, or eren one half-hour of the threo ho spent in parade, to malking "tranchées-abris." Who here mould wish to sce the fate of Eturope, the honour of England, risked in such an unequal conflict, and what General would expose his troops to be thus helplessly slaughtered?

Then look at Alma. Our adrance-nearly 2,000 yards-over gronnd swept everywhere by the fire of the enemy's guns, at marked ranges; the storming of the great redoubt, up 200 fards of a glacis slope, in the tecth of guns and musketry; the advance of the Guards "in an

* "Siborne's Waterloo." There appears also to hare been an abatis across the Charleroi Road, near tlie sandpit.-C.G.

$\dagger$ Picton's dirision at this time was in battalion colmmns at deployiug intervals, as we read that ho did not deploy his troojs until after the retreat of the DutchBelgians (Bjlandt's brigade).-G. G. 
"arrag which was all but found fault with for being too grand and too " majestic." Would this be possible against guns such as those used at Dartmoor, and rifles such as the Martini-Hemry, in tho iands of an cnemy practised in the art of getting corer? Of what avail would be the splendour of our line-the majestic grandeur of our advanecagainst an intrenched body of troops, who would show only the peaks of their caps and the muzzles of their rifles, cach rifle being kept steadily resting on the bank before them, and rolleying destrnetion at the rinte of 10 to 15 roundst a minute? Eren, with the arms he had, snpposing Menschikoff had intrenched himself, conld we hare stormed the Alma heights as we did, or, indecd, should we hare attempted it?

What prevented our assaulting Scbastopol as soon as we arrived before it? Not the ditches, or escarps of the fortifications (which indeed were at that time mere hasty intrenchments growing under our ejes), but our knowledge that works, the approaches to which are well commanded by artillery, cannot be taken except with terrible sacrifice of life, and we knew that, situated as we then were, repulse meant ruin.

I cannot sec how, then, we can aroid the conclusion that in future wars, our soldiers will have to protect themselves in the sarue way as the soldiers of other armies, and that for this we must prepare in times of peace, or we may find it too late when war arrires, and vainly oppose human daring and self-devotion to the inexorable laws of the science of destruction.

Granting, then, that our troops must shelter themselres, it remains for us to cousider the means. 'The question of the transport of tools is one that is surrounded by great difficulties; the root of it is this: Shall the soldier in future carry his tools himself, or get them carried for him? There is strong authority for the former nethod. Colonel Brialmont states that in hussia, the system of giving every man a lool to carry is on trial; that in Denmark, a tool has been given to each file; in Prussia, to the soldiers of the Jäger battalions only; and that, in the American army, the tools of each battalion are carried according to roster by the men of two companies. $\neq$ (Appendix IV.) Colonel Brialmont himself is in farour of the soldiers carrying their own tools, as their doing so would diminish the "impedimenta" - the transport-of" the Arms, and accelcrate the execution of the work. The Drill Committec, in reporting. on the instruction of regiments in intrenching themselves, have arrived at the same conclusion, considering that by any other system of transport, the tools would not be at hand when required. There can be no doubt but that there are very strong reasons in favour of adopting this system, and it has the approval of very high anthority. Napoleon himself wished erery soldies to have a pioneer's tool, $\S$ and indeed made an attempt to get every sapper to carry one, offering "to make it more palatable," that "it should be of

* Finglake's "Crimea." Quoting obscrration of a French Omicer.

t Of course this rate of fire could not ie kept up, but a fraction of a minato might be sufficicnt.-G. G.

I "La Fortification Improsisće," p. 39.

\$ "Jemoirs at St. He!cux," Moutliolon i, pp. $215,219$.

vol. xir.

2 I. 
"superior manufacture, and an implement de luxe, as it were; but "after much discussion on the objections raised to putting this addi" tional weight on a class of men who frequently had to set to work " immediately after a march (and this will not" often be required from " all classes of the troops), he was obliged to abandon t!ie idea."("Hasty Intrenchments in the Ficld," by Sir J. 'T. Burgosne.)

This diffeulty of weight, before which the great military autocrat had to bow and snbmit, now stands before ns, and demands our careful consideration. Many consider that in these days, quick manourring and necessity for rapid motion when adrancing under fire, will make it obligatory to reduce the weight carried by the soldier below what it has erer been before; and it is a rery common opinion, since the short campaigns of Italy and Bohemia, that it will be unnecessary to load him with so much personal kit. The recommendations of General Eyre's Committee embodied these opinions, and I have collected all the information I could find on the comparative weights of different kits (see Appendis V), which I will not now trouble you with. It is suffi. cient to state, that it is quite fensible to gire the soldier au intrenching tool, to increase his prescut allowance of ammunition from 60 to 100 rounds, and yet to gire him less to carry than he has at present, thins:-

\begin{tabular}{|c|c|c|c|}
\hline \multirow{2}{*}{ Articles to be carried. } & \multicolumn{2}{|c|}{ Weights (approximate). } & \multirow{2}{*}{ Remarks. } \\
\hline & As at present. & As proposed. & \\
\hline Arms and anmunition.... & $\begin{array}{l}\text { lbs. } \\
16\end{array}$ & $\begin{array}{l}\text { lbs. } \\
20\end{array}$ & \multirow{7}{*}{$\begin{array}{l}\text { Inclading } 100 \text { rounds } \\
\text { of ammunition, the } \\
\text { same as the present } \\
\text { Frencls wat allow- } \\
\text { ance. } \\
\text { For details of Kit, sce } \\
\text { Aplendis No. V. }\end{array}$} \\
\hline Accoutrements and pack .. & 10 & 4 & \\
\hline Clothes on person ........ & 11 & 10 & \\
\hline Kit, with blanket ....... & $14 \frac{1}{2}$ & $11 \frac{1}{2}$ & \\
\hline Food and water .......... & s & 8 & \\
\hline Intrenching-tool $\ldots \ldots \ldots$ & .. & 3 & \\
\hline Total $\ldots . . . . . .$. & 593 & $56 !$ & \\
\hline
\end{tabular}

But, in attempting to solve this question, the feclings of the soldier himself must be taken into account, and it will not do to answer it merely by making out an arithmetical statement of weights, and supposing it to be a matter of indifference to him what he carries, and that he onls concerns himself with its weight. $\Lambda \mathrm{t}$ present, I fecl con. vinced, though I say it with regret, that the British soldier would consider it a great burden and grievance were he to hare to carry an intrenching tool in addition to his kit; that he would feel that extra 3 lbs. more than all the rest, and that telling him that the rest of his kit had been lightened on purpose would be of no use. This feeling, or prejudice, is no donbt remediable, and I feel sure that the time will 
come when the British soldier will value his spade as second only to his rifle, nerer to be put aside in the field.

Assuming, then, for the present, that the soldier does not carry his intrenching tool, there remain the thrce systems of transport to select from, the Army Service, the Regimental, and the Royal Lngincer Train. By the first tro methods, it is very doubtful whether the tools wonld erer bo at hand when required, as they woukd be mixed up with all sorts of other stores, and in the not unlikely contingeney of deficiency in transport, the tools would probably be left behind in deference, perhaps, to urgent demands for such stores as prorisions, ammunition, clothing, dc. The Engineer Train, on the other hand, would feel it a point of honour to have the tools rrell up to the front; to them their tool-carts would be what their guns are to the artillery; they also would know tools requiued repair, and draw on the reserres accordingly. It would, liowerer, be necessary to take precnutions for obriating the oljection made to this system of transport by General Faidherbe, "that "supposing a battalion cxpects to be attacked, and "wants to get corer, it is nccessary" to get the Gencral of Division to "give an order to the Engineers of this division to supply tools." ("Isa Fortification Improviséc.")

I would propose that cach brigade should hare a detachment of the Royal Engincer Train, who would earry the light shelter-trench tools - for the infantrs (one to erery three men of the brigade), in addition to the ordinary engincer field equipment. Tho shelter-trench tools for one brigade would all pack in a wagon (sec Appendix VI), and should be entircly at the disposal of the Officer commanding the brigade, or, indecd (if thought desirable), they may be issued to Commanding Officers of regiments. When approaching the enems, these tools should be issued as required, each being provided with a light strap, so as to be carried without interfering with the use of a man's arms. I do not fear that, in presence of the enemy, and with full proof of its value, the soldier would object to carrying an intrenching tool. In the adranced trenches before Scbastopol, when night sorties were expected, I often found the men of the working parties would not part. with their rifles, but carry them on one shuulder, and their filled sandbags on the other, sometimes, oring to scarcity of earth, a considerable distance.t

This same fecling which led these hard-worked men thus roluntarils to submit to extra labour, in order to bo effective if attreked, would soon teach their successors to keep their spades as well as their rifles.

* "Rerue Militairo Française," August, 1869.

+ Thus, too, worbed the Jems of old at the repairs to the ralls of Jerusalem, under their inspired prophet-leader. "For the builders crers one liad his sword "girded by his side, and so builded" (Nehemiah, iv, 18). Is a precedent for our" shelter-trench drill, we might refer to rerso 16 of this chapter, where we read, "And "it came to pass, from that time forth, that the half of my scrvants wrought in the " work, and the other half of them held both the spears, the shiclds, and the bows, "and the habergeons."

I A mero caprice will sometimes induce a soldier to load limself leerily for a 2 เ 2 
Whaterer system of transport we adopt, it is certain that it must be one which will ensuro the tools being always at liand when required. Here, again, Waterloo supplies us with au illustration. As Englishmen, we do not, of course, like to admit that at ans period of that great battle we appeared likely to lose it. 'Yet many writers, and among them General Sir J. Shaw Kennedy (who was present as General Alten's Assistant Quartermaster-Geueral), consider that, when La Haie Sainte was taken, the allied Army was in great peril. "The possession of La " Haie Sainte by the French," he writes, "was a very dangerous incident. "It uncovered the rery centre of the Anglo-Allicd Army, and established "the enemy within 60 yards of that centre. . . The danger was immi"nent, \&c. . . . Most fortunately, Napolcon did not support the acl"vantage his troops had gained at this point, by bringing forward his " reserves. This peril was nndoubtedly, in a great measure, the fruit " of the rast importance of holding La Haic Sainte, not haring been "secn, and the consequent neglect of its defences." : Colonel Chesncy corroborates this statement of the critical state of the British Army at this period, and quotes the concurrent testimony of a number of foreign writers. The common reason assigned for the loss of this important post, is the want of ammunition; but, as General Kennedy says, "this is unexplained;" and Siborne supplies another, which may help us to understand why the brave German garrison failed at last after repeatedly repulsing the desperate assaults of the French. "The "mule laden with reginnculal trenching tools had been lost the day "before, so that not even a hatchet was forthcoming."-(Siborno's "Waterloo," rol. i, p. 337.) This was a grievous misfortune, especially as, with the recklessness of soldiers, the garrison had weakened their defences on taking possession of the farm on the erening of the 17 th, by breaking up the great barn door on the west side for firerrood on that wet, checrless night, so that, in fact, they made a breach in their citadel for the enemy to enter by, and in the absence of their tools-with "not eren a hatehet"--they seem to hare been unable to stop it up, for we read that the French constantly attacked at this open end of the barn, and nltimately made their way in through it.

Now, if the course of history could be rerersed-if the early display of the Prussian force had not drawn off 16,000 troops from Napolcon's reserves, and he had pushed the adrantage gained by him throngh the capture of La Haie Sainte, might not the historian of that campaign hare pointed warningly to that stray mule of the 2nd battalion King's German Legion as having carried the fate of Europe on his back? Would that loss hare happened had these tools been in charge of the Royal Engineer Train? I answer No, confidently; and ask in return, do wo ever hear of stray guns of the Royal Artillery being missed in this way?

One branch-perhaps I ought rather to call it the root-of this subject remains for our consideration; but I hare only time to allude very

march ; thus Sir J. Burgorne relates how, in the Peninsula, onc man, a slocmaker, earried a lapstone-another soldier a pet dog-in his pach.-G. G.

* "Notes on the Battle of Waterloo," by the late Geacral Sir Jas. Shaw Ireuncds, I.C.B., \&c., \&c., Pp. 123, 121, 127, 120 . 
bricfly to it. Our Army, to be prepared for war, requires, above all things, instruction and practice in field enginecring; and with a School of Military Engincering at Chathan, it appears strange that measures are not taken for passing regiments suecessirely through a course of field works. The Drill Committec, in reporting on the instruction of reginents, \&c., have, howerer, recommended this measure, and also thint regiments should send Officers and Non-Commissioned Oflicers to the Rogal Engineer establishment to form classes, as at $\mathrm{H}_{y}$ the, so that we may hope to sce this soon carricd out, and also that at all stations where there is ground arailable, the troops may be exercised in forming these trenches. It is the wish of many (and I beliere it would act most beneficially on the morale and physique of the Army) to have a corps d'élite of pioncers in erery regiment. Men of good character, and for the most part knowing some trade-facility for lcarning trades being afforded to all-these men to be trained at Chatham, ancl cmplosed under a Regimental Officer of Works, to be arailable in time of pence for repairs to barracks, and in the field, for cngineering duties in connection with their regiments. But the most skilled workmen will be often little better than useless unless their own offecers can direct them. Each officer should, therefore, be trained to choose positions, and to lay out intrenchments, availing himself of all untural advantages of the ground. The want of this instruction was often sererels felt in the Amcrican war. Thus, we read in the reports from the Armyof the Potomac:-

"Often the greatest difficulty has been in getting an Army to take " up a proper and exact line of defence at first, each regiment, com" pany, and man digging when they find their spades, without refer" ence to the fitness of things, indicating the necessity of more " Engineer ofliocrs."

It is, however, in no self-secking spirit that this is put forward, and I do not think the duties here referred to are such as need Engineer officcrs exclusively for their performance. Well instructed line oflicers shonld be quite capable of performing them, though Finginecr officers should be at hand to give advice and assistance as required. Study and practice is all that is wanted to make our Line officers cqual to any such emergency, and they must bear in mind what Frederick the Great was in the habit of saying to his officers, "If jou wish to learn the art of war, study fortification."

Ilie Ginsmis--Gentlemen, I am sure that you will all join with me in thanking Colonel Graham for the interesting address he has so kindly given us, on this most impertant subject-a subject that increases in importance. with erery fresh dovelopment of the destructive: powers of guns and swall arms. More than thirty years ago, Sir Willian heid, to whom reference has been made by Colonel Graham, wrote, that " 110 army can be complete in its code of field.exercise, " unless that code includes rules and exercises for intrenchments in " battle;" and again, that "the infantry soldier should be tanght,

* Were our existing regulations on this subject merely carried out in crery regiment as dirceted, paragraphs 371,372 , "Qucen's Regulations," a step rould bi gained.-G. G. 
" while he is yet a recruit, that the construction of intreuchments is " a part, and a very important part, of his duty." This, I trust, will now be the case in the British Army, as a "Shelter Trench Exercise" has been introduced into the proposed new field exercise, which will next week be submitted to.H.R.H. tho Duke of Cambridge. And I venture, moreover, to hope that the School of Military Engineering at. Chatham will turn out as many skilled instructors and workmen, as the School of Musketry at IIythe does of rifle instructors and lirst class shots.

Aprexid No. I.

Portable Defences.

Sercral differcnt propositions lare béen made for utilizing the knapsacks as corer for troops when advancing under fire. Captain Chamin, of the Belgian service, and Captain Bennet, of the 7th Fusilicrs, propose making the knapsacks musket proof by plates of steel or alumininm.

Mrajor Frank Bolton proposes that each man should carry a steel spade with a morable handle, outside the great coat, the spade answering the purpose of the metal plates in the first proposition; it has also the adrantage of adjusting itself to the new ralise equipment, whereas the first mentioned would require us to retain the old form of pack.

Under the supposition of troops firing from behind cover, and others making a rapid clarge, these heary plate-laden knapsacks would be at scrious cncumbrauce, besides troops firing behind them could never improve their defences, as occasion might require. Major Bolton's plan is not open to the same objection, prorided the men are to be taught to use their spades, and not merels lie down behind them, indeed the best pattern of steel spades (the American) has an area of only fire square inches, barely enough to cover a man's head. Major Bolton makes no mention of pickases, which, howerer, would be necessary if the spades are to be used. One great objection to the use of the pack as a defence is that once laid down for that purpose, it would generally in the course of an action be lost sight of," and only recovered with great difficulty, if at all. As Napolcon said, the soldier should nerer part with his pack.

Captain Harcourt, of the 102nd Fusiliers, has another suggestion to make for obtaining corer. He proposes "that a sandbag and trowel "form part of the equipment of every infantry soldicr," the sandbag and trowel to fit in a case weighing altogether $1 \mathrm{lb}$. 3 ozs.

Captain Harcourt states that with this implement, a sandbag can bo filled in from two to five minutes, and that a man lying down behind the filled bag is concealed from viow at 100 to 150 yards. Having had this trowel and bags forwarded to me by Captain Harcourt, I made an experiment at Chatham with the following results:- 
1. With the new London trowel, a sapper (a rery good workman) filled the first sandbag in 31 minutes, the second in 4 minutes, 1 fing covered behind two sandbags, in 8 minutes.

2. From the time of standing at atterition with Captain Harcourt's pouch on (containing sandbay and trowel) to the time of lying down behind one sandbar, 4 minutes. In this case, howerer, he was certainly not concealed nor sheltered, although zealously striving to be, and reminding spectators somewhat of the popnlar story of the ostrich.

3. $\triangle$ shelter pit, such as that shown in Figs. 8, 9, 10, plate XXXV, was then thrown up by the same man in the same soil, with ordinary intrenching tools in 4 minutes, giving complete corer.

4. The same sapper then set to work to make a similar pit in the same soil with Captain Harcourt's trowcl, and worked hard for 11 minutes without quite completing it. The soil was gravel and stones, nnderlying a top crust of about five inches turf and regetable monld. As the trowel had not to go below the mould except in No. 4 trial, the soil was favourable for it.

ArPE:AlY No. II.

\section{Comparative poucrs of Snooth-bore and Rifled Artillery.}

The chance of hitting a target 1 metre square, at a distance of 600 metres, with the smooth-bore with 8 lbs. charge, is 4 per cent.; with the rifled Belgian gun of 12, and with a charge of 1,450 grammes 80 per cent. Probabilities of hitting a target 3 metres broad by 4 high with the French 12-pounder howitzer at 1,200 metres is 4 per cent.; with the 6-pounder rifled gun at same distance, 90 per cent.-(Taken from " Etudes sur la Défence des Eitats," by Col. Brialmont.)

Captain Noble calculates, according to results obtained with a 9-pounder smooth-bore and a 9-pounder Armstrong gun, at ranges varying between 900 and 1,100 yards, that the probable crror in the range of the rifled gun is.................. $7 \cdot 4$ yards.
Do.
do.
smooth-bore. .......
$47 \cdot 2$
Do.
oriation of the rifled gun.
$9 \cdot 8$ inches.
Do. do.
smooth-borc. ........
8.8 feet.

("On the Theory of Probabilities in Artillery Practice," by Captain Noble.)

The following rectangles for smooth-bore 9-pounder, 9-inch rifled muzzle-loading 9-pounder were obtained from experiments at Shucburgness :-

\begin{tabular}{|c|c|c|c|c|}
\hline Gun. & Eleranion. & Range. & Rectangle of fire in yards. & Remarks. \\
\hline $\begin{array}{l}\text { 9-pr. S.B. .. } \\
\text { 9-pr. Rillcd } \\
\text { I.L. }\end{array}$ & $\begin{array}{l}2^{\circ} \\
2^{\circ}\end{array}$ & $\begin{array}{l}085 \text { yards. } \\
1,083, "\end{array}$ & $\begin{array}{r}147 \cdot 2 \times 9 \cdot 1 \\
10 \cdot 7 \times I \cdot 1\end{array}$ & $\begin{array}{c}\text { Clarge } 1 \mathrm{lb} . \\
5 \text { ozs. }\end{array}$ \\
\hline
\end{tabular}


Trial at Shoeburyness by O.S. Committee, Juno 13, 1867, on three Rows of Targets, 45' $\times 6^{\prime} \times 2^{\prime \prime}, 15$ yards apart.

\begin{tabular}{|c|c|c|c|c|c|c|}
\hline $\begin{array}{l}\text { Gun and pro- } \\
\text { jectilc. }\end{array}$ & Charge. & $\begin{array}{l}\text { No. of } \\
\text { efrectire } \\
\text { rounds. }\end{array}$ & $\begin{array}{l}\text { Jean } \\
\text { range- } \\
\text { yards. }\end{array}$ & 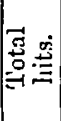 & $\begin{array}{l}\text { No. of } \\
\text { hits per } \\
\text { effectire } \\
\text { round. }\end{array}$ & Remarks. \\
\hline $\begin{array}{l}\text { 12-pr. B.L. rilled } \\
\text { Segment-shell.... } \\
\text { 9-pr. S.B. ..... } \\
\text { Shrapnel....... }\end{array}$ & $\begin{array}{l}\text { Charge 1:5 lbs. } \\
\text { Burster } 550 \text { grs. } \\
\text { Charge } 25 \text { lbs. } \\
\text { Burster } 192 \text { grs. }\end{array}$ & 23 & $1,21-1$ & 510 & $9 \cdot 6$ & $\begin{array}{l}\text { Recorded in } \\
\text { Appendix D, } \\
\text { of Report on } \\
\text { Slingnel } t \text {. } \\
\text { Segment } \\
\text { Committce. }\end{array}$ \\
\hline
\end{tabular}

Experiments were also tried with the 12-pounder shrapnel, which are not admissible in a comparative statement, as at that time the proper length of fuzes had not been accurately determined.

$\triangle$ PPEXDIX NO. III.

Martini-Henry Riflc.

Captain Drake, R.E., Musketry Instructor at Graresend, has kindly furnished mo with the following interesting summary respecting the powers of the new weapon :-

" 1 . The penetration at 700 is about equal to that of the Enfield at " 350 yards.

"2. Its accuracy at $1,000=$ Enfield at 600 yards.

"3. Its rapidity $=$ Snider $\times 2=$ Enfield $\times 5$.

"That is Snider $=\frac{5 \text { Enfield }}{2}$.

"In two minntes fire men with MIartini-Henry rifles will produce " twice the effect of ten men with Sniders, owing to superiority both of " accuracy and rapidity, and ease of loading."

In the case of an assault on troops posted behind a shelter-trench, and armed with the Martini-Henry, supposing "distance to adrance " 600 Jards, attacking party 400 strong, defenders (Martini-Henrs) "well sheltered 100 strong, 50 to fire and 50 to provide them with " ammunition, time adrancing thrce minutes, by the end of the second " minute there ought not to be a man left standing. With the Enficld $\therefore 80$ men ought to be hit in the same time; with the Snider, 160."II. D.

Lieut. Stephens, R.E., Assistant Musketry Instructor at Graresend, has also been kind enough to gire me the subjoined information respecting rolley firing with the Ifartini-Henry:- "It was found in firing " 100 rouuds per man by volleys at 800 yards with a section of five " men armed with the M[artini-Henry rifle at an ordinary volley target " $6 \mathrm{ft}$. by $12 \mathrm{ft}$, in rough winter wentler, that a percentage of 50 lits "was made. 
"On onc oceasion, four men firing by volleys at 600 yards with the " same arm, made a percentage of 85 when firing 50 rounds.

"It was found that at both these ranges 10 rounds by volleys could "be easily fired in less than a minute and a half; indeed that was the "actual time taken for any 10 rounds of the abore practices when no " harry was made.

"Fifty per cent. of hits would be good for rolley firing with the Snider "Enficld rifle at 400 fards, and 10 rounds by collegs with this arm "could not be fired with effect in less than two minutes and a half.

"The last-named rifle would be of no use for firing in the ranks at " long distances.

"Independent firing with the Martini-Henry rifle at long distances, "although good, was not so effective as rolley firing, and on service " would cause great waste of ammunition.

" On one occasion, tive men firing independently at a rolley target at " 300 yards with the sights up for two minutes (tle time usually taken " to fire 10 rounds with the Snider), placed 112 hits on the target, " having fired betwcen them 121 rounds, out of which two cartridges " missed fire.

"M Men leaning against the parapet of a shelter-trench, besides being " protected from the shots which might actually strike the parapet itself, " would bo a most difficult mark to aim at, and consequently most of "the shots fired at them would go orer or fall short of them, while they " on their part, with the parapet for a rest, would be in a most excellent " position for firing with accnracy."

APpexdix No. $\pi$.

Experiments with Tools.

An ingenious shovel, the invention of Capt. Linneman, of the Damish Army, was tried at Chatham.

Weight of shorel $\quad \ldots \quad \ldots 1 \mathrm{lb} .12$ ozs.) On one side of the blade is Ditto of scabbard and belt $0,10 \frac{1}{2}$, i saw, the other an axe; Total weight ... .. 2 lbs. 61 ozs. $\int \begin{aligned} & \text { the whole blade. } \\ & \text { make a frying-pan. }\end{aligned}$

In rery casy soil, such as sand, they werc found to do very well, but they are useless in dificult soil, as they hurt the men's hands; the saw-edge gets destroyed after very little work, and the axe-edge gets blunted.

Experiments were also tried with a pickaxe and shorel proposed by Col. Bray, and two patterns of $\Lambda$ merican shorels. The portion dug out by cach was $\Psi^{\prime} \times 2^{\prime} \times 1^{\prime} 3^{\prime \prime}$ deep, in rather difficult soil, though soft from wet. 


\begin{tabular}{|c|c|c|c|c|}
\hline Tools. & Weight. & $\frac{0}{0}$ & $\begin{array}{c}\text { Time taken to } \\
\text { complete. }\end{array}$ & Remarbs. \\
\hline $\begin{array}{l}\text { Scrrice piek } \ldots \ldots \ldots \\
\text { And shovel ........... }\end{array}$ & 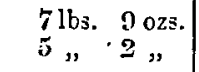 & \} 10 & 11 minutes & \\
\hline $\left.\begin{array}{l}\text { Colonel Bragg's .... } \\
\text { Pick and shorel .... }\end{array}\right\}$ & $\begin{array}{l}\text { P.5 lbs. Gozs. } \\
\text { S. } 4,11 \frac{1}{2},\end{array}$ & \} 10 & 1.t1 minutes & $\begin{array}{l}\text { Rather clumsy, con- } \\
\text { sidering its wcight; } \\
\text { thumb-screm and } \\
\text { blade-work loose. }\end{array}$ \\
\hline $\begin{array}{l}\text { Chatbam pick....... } \\
\text { American shorcl, No. } 1\end{array}$ & $\begin{array}{ll}2 \text { lbs. } & 8 \frac{1}{4} \text { ozs. } \\
2 \| & 1 \frac{3}{4},\end{array}$ & \} 10 & 11 minutes & $\begin{array}{l}\text { Soil rather casicr } \\
\text { than the others, } \\
\text { pickare broken be- } \\
\text { fore completion, } \\
\text { which causcd some } \\
\text { delay. Best sapper } \\
\text { working. }\end{array}$ \\
\hline $\begin{array}{l}\text { Chatham pick....... } \\
\text { American shorel, No. }\end{array}$ & $\begin{array}{l}2 \mathrm{lbs} \text { I0lozs. } \\
2,3 \mathrm{~s},\end{array}$ & \} 10 & 16 minutes & $\begin{array}{l}\text { The rounding of the } \\
\text { corners presents the } \\
\text { foot being used witl } \\
\text { this shorel. }\end{array}$ \\
\hline
\end{tabular}

A crutch is much wanted on the ends of the handles of the American shorels. The steel blades clean themselres much better than the blade of an ordinary shovel. The shovel without the shoulders ronnded off (No. 1) can be used very well as a spade, the blacle being stiff and strong, and there boing plenty of room for the foot. The blade might with advantage be made a little longer, and the liandle perhaps a little lighter towards the ends, so that with erntch the whole weight may not exceed 2 lbs. 8 ozs. It was considered that this would makc an admirable tool for infantry to carry for shelter-trenches. 
ArREXdix No. V.

Weiglts camiel in the Field.

Britisn.

\begin{tabular}{|c|c|c|c|}
\hline \multirow{2}{*}{ Articles. } & \multicolumn{2}{|c|}{ Approximate weiglits. } & \multirow{2}{*}{ Remarks. } \\
\hline & $\begin{array}{c}\text { As at } \\
\text { prescnt. }\end{array}$ & As proposed. & \\
\hline Rifle and bayonet ........ & $\begin{array}{l}\text { lbz. oz. } \\
100\end{array}$ & $\begin{array}{l}\text { lbs. oz. } \\
100\end{array}$ & * Made up to 100 rounds, the \\
\hline Immunition .......... & 60 & $10 \quad 0^{*}$ & cica wit divon- \\
\hline Cantecn...$\ldots \ldots \ldots$ & 18 & 18 & Committec. \\
\hline Pack and accoutrements... & 102 & $13 t$ & 1 bs. oz. \\
\hline Ficld kit.............. & 80 & $\overline{\mathbf{j}} \quad 0_{+}^{+}$ & 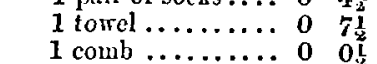 \\
\hline Clothes on person ........ & 110 & $100 \$$ & 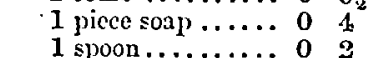 \\
\hline Water bottle and mater ... & 20 & 20 & $\begin{array}{l}1 \text { shocbrush } \ldots \ldots \ldots \text { o } \\
1 \text { clasp.huife. }\end{array}$ \\
\hline Three days' prorision..... & 60 & 60 & Thircad, ncedles, sc. 0 of \\
\hline Blankct............... & 50 & 50 & 1 pair of shoes ....2 20 \\
\hline Intrencling tonl.. & $\ldots$ & 30 & Total...4 49 \\
\hline Total... & 5910 & 5611 & $\S$ Deducting clunco. \\
\hline
\end{tabular}

Fnexcer.

Weight of arms and cquipment, 1857... 72 lbs. 4 As giren by Dr. Parkes, ("PracOr, adding $10 \mathrm{lbs}$. for clothes on person.. 82 "\} tical IIygiene," p. 371.

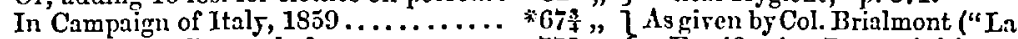
Or, adding 10 lbs., as beforo ......... $77 \frac{9}{4}$, fortification Improriséc").

\section{Atstrias.}

Weinht of arms and equipment, 1869 .... 49 lbs.t English. Adding $10 \mathrm{lbs}$. for clotlies on person .... 59 ,"

* Made up as follors:-

Arms and necessarics ............ 20

60 cartridges .................. $2 \cdot 1$

$\begin{array}{lll}\text { Tente d'abri, blankets, dc. ............. } & 5 \cdot & 11 \\ \text { Rations for four dass, without meat } \ldots . . & 3 \cdot 10 & 7 \cdot 18\end{array}$

$\overline{30.8} \quad \overline{67.76}$

† Made up as follows :-

Ibs. oz.

Kit, including great cont $\ldots \ldots \ldots \ldots \ldots \ldots \ldots \ldots 15 \quad 3 \frac{1}{2}$

Accoutrements...................... $10 \quad 4 \frac{1}{2}$

Canteen and coolsing-tin $\ldots \ldots \ldots \ldots \ldots \ldots \ldots \ldots$ 4 4 . 0

Provisions ...................... 311

Rifle $\left\{\begin{array}{l}\text { Werndl, with } 72 \text { cartridges } \ldots \ldots \ldots \ldots \ldots \\ 16 \quad 8\end{array}\right.$

with 60 do. 15 lbs. $40 z . .4 \quad \overline{49} 11$

Ditto with Wanzl do........ 48 
BetgIAs.

Theight of arms and equipment.............. 55 lbs. English.

Adding $10 \mathrm{lbs}$. for clothes ou person, as before .... 65 "

Of this I hare no detail. -G. G.

APPEXDIX No. VI.

Transport of Tools for One Brigade.

Lient. Blood, of the R.E. Train, has .kindly supplied me with the accompanying memorandum :-

"For transport of the intrenching tools for one brigade only of the " light pattern, one wagon would be sufficient. The tools would be as "follows:-

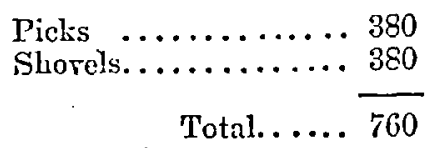

Spare helvos for-

Picks........... 30

Shorels.......... 30

s: The detachment of R.E. Train would be as follows:-

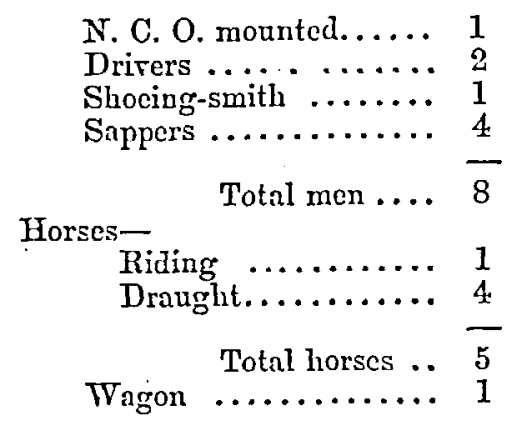

: The wagon would require to be specially fitted up, and when "Ionded would weigh as follows:-

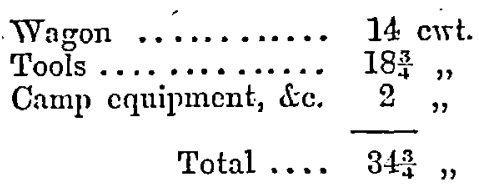

"This would not bo too much for four horses; in fact, a properly " "coustrncted wagon with this load could go any where with infantry." "S. MI. E., "B. Bloon.

"5th MTry, 1870." 